\title{
Beyond blame: \\ leadership, collaboration and compassion in the time of COVID-19
}

\author{
John Forester ${ }^{1}\left[\right.$ George McKibbon ${ }^{2,3}$
}

Received: 25 May 2020 / Accepted: 16 July 2020

(c) Springer Nature Singapore Pte Ltd. 2020

\begin{abstract}
As the COVID-19 pandemic confronts us with our interdependence and vulnerability, we can respond in distinctly different ways. Our fears may prompt blame and its rationalization, but our fears may also motivate inquiry and learning. Compassion and collaboration hang in the balance-shaped in part, we shall argue, by political leadership, scientific expertise, and emergent social solidarity. Blaming others may side-step responsibility, but it will not encourage or target actions in response to suffering. But admitting ignorance and the need to learn, supporting widespread testing, and following best available public health advice might cultivate broader public action and confidence-as evidenced both in exemplary public leadership and in shared actions of mutual aid like social distancing. We argue that public leadership can model and encourage-or discourage! — compassionate and collaborative action, and we examine a striking natural experiment: the parallel COVID19 briefings of the public by President Trump's White House Task Force and New York State's Governor Andrew Cuomo. Although many of our arguments may have widespread applicability, this essay's principal perspective is primarily based upon our experiences in North America, and it is therefore American-centric to a large extent.
\end{abstract}

Keywords COVID-19 $\cdot$ Blame $\cdot$ Compassion $\cdot$ Misinformation $\cdot$ Leadership $\cdot$ Collaboration

\section{Introduction}

As the COVID-19 pandemic confronts us with our interdependence and vulnerability, we can respond in distinctly different ways. Our fears may prompt blame and its rationalization, but our fears may also motivate inquiry and learning. Compassion and collaboration hang in the balance-shaped in part, we shall argue, by political leadership, scientific expertise, and emergent social solidarity. Blaming others may side-step responsibility, but it will not encourage or target actions in response to suffering. But admitting ignorance and the need to learn, supporting widespread testing, and

John Forester

Jff1@ cornell.edu

George McKibbon

georgeh@mckibbonwakefield.com

1 City and Regional Planning, Cornell University, Ithaca, USA

2 School of Environmental Design and Rural Development, University of Guelph, Guelph, Canada

3 W Booth School of Engineering Practice and Technology, Sessional Faculty, McMaster University, Hamilton, Canada following best available public health advice might cultivate broader public action and confidence-as evidenced both in exemplary public leadership and in shared actions of mutual aid like social distancing.

Our argument has the following structure. Section 1 examines issues of interdependence, the vulnerability that creates, and the precarious compassion and collaboration that may, but does not necessarily, follow. Section 2 examines the obstacles to compassion and collaboration posed by fearful responses of blaming others and rationalizing that blame through misinformation in the forms of managing public belief, political consent, and social trust. Section 3 argues that public leadership can model and encourage-or discourage!-compassionate and collaborative action, and then Sect. 4 takes a closer look at a curious natural experiment: the parallel COVID-19 briefings of the public by President Trump's White House Task Force and New York State's Governor Andrew Cuomo. Taken together, these discussions show us in vivid detail how public leadership can shape more or less compassionate and collaborative responses to the pandemic now confronting us. 


\section{Living with interdependence and vulnerability: possibilities of compassion and collaboration}

Unlike natural disasters like those of Hurricanes Sandy and Katrina in the USA, the brunt of the COVID-19 pandemic is neither time limited nor spatially contained. But like those and many other natural disasters, the pandemic confronts us with both misfortunes and injustices (Shklar 1990, p. 46). Threatening to sicken those of no religious affiliation, skin color, economic class or gender in particular, COVID-19 threatens affluent beach goers, Christian worshippers packed into their congregations and nursing home residents alike, along with doctors, nurses, orderlies and hospital workers of every stripe. But yet, we know, the poor and non-white suffer more because they have less access to medical care, they have fewer means to take time off to protect themselves, and they are more likely to be those who are changing the beds in the nursing homes and those who have the most precarious jobs in the food service industries.

This is just the beginning. Yes, historical, inherited relationships of injustice and inequality amplify the consequences of both widespread misfortune and threats to health and welfare. ${ }^{1}$ But the COVID-19 pandemic raises an additional problem, a precarity and vulnerability that is no longer limited to the poor and dependent, to those wondering where their next meal might come from, to those "one paycheck away from losing their homes." Here we have a vulnerability to contagion that can come from sitting next to someone in a soccer stadium, from lying next to someone in a nursing home room, from praying together at a religious service.

So even more than exposing the extensive vulnerability that affluent countries have seen, the pandemic forces us to recognize our increasingly interdependent lives in a globalized world. The pandemic requires planning and policy professionals - and applied social scientists as well-to respond both, then, to widespread and diverse vulnerabilities (of ill-health, economic disruption, and social displacement, for example) and to a palpable interdependence that does not depend on any political, social, religious, or other doctrinal commitment. The isolation of gated communities looks silly in the time of COVID-19. Even more worrisome, though, than self-segregation is the widespread polarization that has led some to heed, but others to spurn, the public health recommendations spread through our electronic media. ${ }^{2}$ Distrust of "fake news" and others' motives can escalate such polarization. But we must figure out how to live together

\footnotetext{
1 Not only does misfortune exacerbate and amplify prior injustice, it makes demands on anyone concerned with justice. Cf. Shklar's far too slighted analysis, e.g., p46: "Though the passively unjust person is first and foremost an ordinary citizen, he is also often a ruler or a public official. Governments that do nothing are often the most unjust of all."
}

and to manage our interdependence and vulnerability, or we will perish together.

Doing that work will require us to seek not only a more just but a more compassionate society as well to respond to the COVID-19 pandemic's ill-health and dislocation, deeply felt loss and trauma (Institute on Trauma and TraumaInformed Care, No date). "Compassion" here requires more than an attitude toward the suffering and vulnerability of others-for compassion involves practical action responding to the plight of others, not just "good intentions" to be of assistance, or in partnership. Moreover, because compassion cannot be imposed, it must be collaborative, even accountable, not one-way but two-way, not a technical solution by an expert to a patient's problem but a collaborative and shared practice together (Lyles et al. 2017; McKibbon 2020b; Forester 1999, 2020).

But such practical compassion, we shall see, is far from easy. In hospitals, nurses and doctors and staff risk their lives to take care of Covid-positive patients. They must confront the fears that their personal protective equipment might run short, might not adequately protect them from this disease about which so little remains clearly understood. Providers of "essential services"- - transport workers, food service employees, delivery workers-must face fears of infection in yet other ways, if they are to respond to the needs of the sick and healthy alike. Residents have been asked to stay home and socially distance - to care for themselves and their neighbors too, wearing masks less for their own protection than to take care that they do not infect others-even as the ease of such distancing can vary with class and culture.

If compassion in the time of COVID-19 involves confronting diverse fears, we should explore what makes that more or less possible. What might give so many of us, from hospital workers to essential service providers to co-workers to neighbors, the confidence-the felt hope-that we can actually overcome these fears? How can effective social collaboration thrive instead of suffer?

\subsection{Contingencies of public confidence}

Having the confidence to overcome fear requires not only personal strength, because the strong can still be foolish. Just as fear depends in part upon information, so too does hope and confidence. The better the information about how to assure personal safety, the more clear the paths to safe conduct may be; the more assured we are by the testing of protective gear, the more confidence we might have about going on with our lives. Good information, good science,

\footnotetext{
2 The retreat into enclaves reflects, Ben Davy suggests, an egoism quite opposite to the compassionate regard of a global citizen. Cf. "One World Together at Home," at globalcitizen.org.
} 
good testing might not necessarily produce courage, but they will be far more likely to produce public confidence and hope in what we can actually achieve than will the claims of politicians promoting home remedies.

But nothing guarantees that hospital or transport workers or even our neighbors have regular access to such "good information," to the results of widespread, reliable testing, to the advice of scientific and medical experts. In this time of COVID-19, as we shall see, we must confront the foes of compassion: fear-mongering, the politics of blame, and willful dis-information.

\subsection{Contingencies of collaboration}

The COVID-19 virus's contagiousness forces us to recognize how our own welfare depends upon the actions of others over whom we have no control, and likewise how the welfare of many others depends on our own actions which they do not control. We are connected, like it or not, and worse, our sickness or health, our freedom to live as we wish, depends on the actions not just of ourselves but of others. We are interdependent, then, both vulnerable and influential too.

So we have choices to make, both about how we wish to act and how we wish others to act: We can pay attention to or ignore each other; we can compete for scarce resources, hoarding masks and gloves and PPE (personal protective equipment) or sharing them as needs arise; we can look to shared norms of social distancing or flout them as we wish; we can try to collaborate to protect public health or we can go our own way, risking our own health and that of others.

In this situation, the incentives to learn and collaborate are strong; we risk our lives by ignoring the needs, feelings, dependency, and risks of others. Acting together means making sense together. Acting together means developing shared understandings of what is possible and how we get there. Even if acting together might seem just strategically sensible, developing such shared strategies — sharing equipment, for example-requires a shared trust, especially when sanctions and enforcement might be dangerously slow.

This suggests that when our health is at risk in the time of COVID-19, our interdependence encourages, if not quite forces, our collaboration-witness the widespread efficacy and adoption of social distancing measures-but that collaboration requires for its stability and depth not just selfcare but a widespread compassion for others as well. ${ }^{3}$ As we

\footnotetext{
${ }^{3}$ For a striking review of non-state-driven, emergent practices of compassion and mutual aid, see Tolentino (2020). David Laws (in correspondence) points out that even social distancing practices, among many other practices of care for others' welfare, "raise the possibility of thinking about a new future, but, in doing so, also highlight how vulnerable such efforts are to blame and other pathologies of interaction. So from the moment we step out our door, we are not
}

understand the risks to ourselves, we might begin to understand the risks to others.

As we recognize our own possible dependency upon first responders, we come to appreciate the risks they face as they walk into the hospitals they staff, as they care for patients at all stages of the COVID-19 illness, as still others maintain our nursing homes, as diverse service workers provide all those "essential services" — whose levels of salary and wages had never compensated them as being "essential" before. Our welfare depends not only on all these caregivers and essential service providers, we see, but upon our neighbors too...our neighbors all across the towns and cities we live in...our neighbors from whom we have learned that we too must maintain a social distance if we are not unwittingly to spread this contagion when any of us are asymptomatic.

Being interdependent drives us to consider carefully, strategically and reliably, then, how we will need to collaborate, if we are to act to understand and address the needs and welfare of others as well as those of our own loved ones and ourselves. "Testing," we may see, is the scientists' disciplined way of a neighbor's asking, "How're you feeling?"

\subsection{Requisites of compassion}

So, acting compassionately and collaboratively will require learning, inquiry, testing, perception, sensitivity (McKibbon 2020b; Nussbaum 2014). We will have to learn, first, about the experiences and needs and hopes of so many of those affected by the pandemic, those sickened or grieving, those displaced or unemployed, and more. ${ }^{4}$ We will have to learn, second, about the causes and sources of others' health risks, shortages of essential supplies, dangers of congregating as usual: how is all this happening?

But all that learning will have to lead, third, to effective action, not to states' bidding insanely against each other

Footnote 3 (continued)

only thinking about but practicing forms of collaboration and becoming sensitive to their vulnerability."

${ }^{4}$ We must recognize widespread vulnerability and suffering; we will need to create spaces where we can be silent and grieve and tell our stories; we must constitute representative and inclusive forums where we can discern motivations and responses as objectively as possible; we symbolize our actions in the form of safe spaces with which hope can operate. Such planning and decision-making processes should adapt rules like these in their construction and operation (McKibbon 2020a, b; Innes and Booher 2010): (1) participants need to be collegial in all their discussions; (2) all the applicable sciences should be applied; (3) evidence-based decision making should be adhered to when providing advice; (4) all points of view among the participants need consideration during discussions and when providing advice. 
to drive up the prices of ventilators, not to recommending the use of household disinfectants to combat the virus, but to devising ways to procure essential supplies and the best available medical advice. Blake Polland et al. (2020, p. 180) explore public health responses in three scenarios, those of: a return to business as usual; risk management; and transition (moving into a future where new problems arise and asymmetries prevail, as we discover and realign existing and future asymmetries at the same time) (Polland et al. 2020, p. 180).

But, fourth, acting sensitively, smartly, and practically will require us to think about ourselves, and our relationships to one another, in new ways: no longer just as strategic consumers meeting in a health care marketplace but now as citizens interacting together, not just as do-whatever-wewish individuals but as members together of communities committed to protecting each other's health, welfare, integrity and autonomy too (cf. Lebano 2020, Lorde 2017).

\subsection{From fear through anger to action}

In the time of COVID-19 interdependence, contagion and vulnerability produce fear. We fear illness itself. We fear overwhelmed hospitals unable to deliver care to the sick. We fear endangering and overtaxing first responders. We fear, not least of all, profiteering suppliers and self-interested politicians apparently favoring their reelection prospects over public health suffering, and more. ${ }^{5}$ We can face these fears of loss-of personal connection and social interaction, loss of loved ones, loss of income, loss of housing and jobswith resolve and anger that motivates us to act, but how?

The deceptively easy way forward is to wish to "throw the bums out," to blame the incompetent administrators, to blame the right-wing media that spreads mis- and dis-information, to blame elected leaders for dismissing intelligence warnings and failing to act, etc., and so we might resist them: We might attack their malfeasance, ridicule and discredit them, blame them in myriad ways for the damage done by lack of preparation, rumor-mongering, false-hope spreading, putting people at risk as they have (cf. Nussbaum 2016, p. $32-33,92-93){ }^{6}$

\footnotetext{
${ }^{5}$ Reviewers of this paper have pointed to examples of such politicians east and west, north and south.

${ }^{6}$ Nussbaum suggests, though, that much of this kind of action on our part can involve "magical thinking." We might attack the blameworthy and imagine payback and retribution, but will that in itself safeguard anybody's health? What will take still more thought and be still more important, if less revengefully satisfying, Nussbaum argues, is to work to set things right: not through fantasy or wish-full thinking but through critically realistic hope and confidence, through wellinformed strategies of tested means: practical experimentation exploring new strategies of prevention, mitigation, care and even social organization - new asymmetries and realignments-acting risk by risk, malfeasance by malfeasance, health threat by health threat, in a publicly accountable, transparent and objectively efficacious way.
}

But anger can serve us or it can side-track us; more dangerously still, blame - whether justified or not—can provide a much too simplistic way out (Nussbaum 2016, p. 35-40, 2018). Blame allocates responsibility, but it does not craft new proposals for action. ${ }^{7}$

Here we can learn from mediators' practices that seek to re-channel the animus and energy of parties' anger toward creating and crafting new options, new ways of going on together. These moves do not ask for "hope" to replace action. They ask for action as a concrete, actual expression of possibility, as a setting out of "what we could do...". These are moves of reaching out-as in the current pandemic - to partner with others, to make masks as thousands did, to support local food pantries as others did, and to offer a clear and expertly informed path for action together, closing, and reopening businesses in phases. These are moves made to provide a sense not of anxiety but an informal confidence that "here's how we can take care of ourselves and each other."

\footnotetext{
${ }^{7}$ Public dispute mediators who work with antagonistic and distrusting parties face these problems all the time. Consider two examples: (1) In working with bitter adversaries who had been vilifying and suing each other about property rights and environmental management for 20 years, mediator Lisa Beutler found herself addressing stakeholders repeatedly, "Yes, you have attacked each other in the past, and, yes, you might continue in those cycles of retribution and revenge, but here is the question: Are you willing to be in a conversation here and now...to do better, to prevent future suffering, to create another path forward?"(Forester 2009, p. 146); (2) McKibbon was a witness at an Environmental Assessment Board Hearing in the Province of Ontario that extended 10 years from conception of the project to release of a final decision by the Environmental Assessment Board. He provided evidence for Nishnawbe-Aski Nation, a treaty organization representing 44 communities in the James Bay and Hudsons Bay watersheds in Northern Ontario, and Windigo First Nations Council represented 7 communities in northwestern Ontario. McKibbon set out principles for forestry planning that addressed First Nations concerns and that were eventually used to develop a settlement agreement. Alan Grant, a negotiator, also set out his evidence including his observation that "the fact must be faced that the Europeans did not necessarily see the original inhabitants as human. The scars of this historical baggage have not been removed from our society."

${ }^{8}$ Cf. Orhan Pamuk, winner of the 2006 Nobel Prize for Literature, on "What the Great Pandemic Novels Teach Us,": "When I watch the televised images of people waiting outside the world's biggest hospitals, I can see that my terror is shared by the rest of the humanity, and I do not feel alone. In time I feel less ashamed of my fear and increasingly come to see it as a perfectly sensible response. I am reminded of that adage about pandemics and plagues, that those who are afraid live longer. Eventually I realize that fear elicits two distinct responses in me and perhaps in all of us. Sometimes it causes me to withdraw into myself, toward solitude and silence. But other times it teaches me to be humble and to practice solidarity." (Pamuk 2020).
} 
This harnessing of anger is not "planning" for plans' sake; it is planning for courage's sake, for confidence's sake, for realism's sake. ${ }^{9}$ This is not planning and compassion as "good intentions" and wishful thinking, this is compassionate planning for effectiveness, not for wasting time and effort but for maximizing return, for knowing when I have to get through difficulty and when I can go back to work and not fear for my life, for knowing when I can arrange for play dates and family gatherings for my children without fear of endangering anyone. This is compassionate planning not for obsession with fear and insecurity, but for practically imagining what I can do now with my neighbors and loved ones, planning not for being immobilized with fear but planning for living in the world again. ${ }^{10}$ But as we shall see, public leadership can enable or undermine such collaborative and compassionate action.

\section{Foes of compassion: blame and the managing of belief, consent, and trust}

\subsection{Blame as an obstacle to compassion}

Just as fear can produce anger, ${ }^{11}$ anger can fuel not just moral judgment but a process of blaming that weakens rather than strengthens community rebuilding, undermines rather than promotes community health, and obstructs rather than enables collaboration and compassion.

Consider how blaming behaviors can undermine collaboratively acting together. Blame marshals antagonism to point the index finger at the other; you have done this and done it

\footnotetext{
${ }^{9}$ For example at the American Planning Association's National 2020 Conference, on Wednesday April 29, Julia Freedgood observed the major supply chain problem laid bare by the pandemic is the majority of the US food supply comes from 9 counties, most of which are in California while about $90 \%$ of the small and mid-sized farms in America are struggling financially.

${ }^{10}$ Writing about Peter Marris's work in planning, Leonie Sandercock suggests, "[T]he COVID-19 crisis is presenting the US (in particular) with an existential crisis about meaning and... the real battle for recovery is less about the economy than about a sense of belonging/ attachment, or not, to something meaningful. In this sense, the work of planning is about more than proposing collaborative rather than competitive processes: it's about a language of repair and rebuilding, from the bottom up, thinking about how we might live together in reciprocity and neighborliness: an ethic of care, for each other and the planet." Personal correspondence, 5/13/20.

11 Anger can fuel the desire for retribution, as if the violence we do to a perpetrator will bring back what we have lost (Nussbaum 2016, p. 17, 2018). Nussbaum does not dismiss the idea of deterrence-the notion that the likelihood of punishment can deter criminal behavior, for example-but she explores the more subtle problem of the ways that anger is corrosive. Nussbaum observes that fear and narcissism are inter-related and both reinforce anger and promote violence-all of which is easier when social polarization exists, whether that be economic, social or racial.
}

wrongly. But to act together requires the courage to offer our hand to one another: could we do this, or do that?

The stridency of blame divides us. Blaming the other, we have decided we know what's gone wrong and why, and that the Other is the problem. But floating a proposal brings us together; asking the other, we claim not already to know and presume but to wonder what is possible. Blame conveys a presumptively closed judgment; offering a proposal presents an open question-one that one "I" makes to another "I"that a subsequent "we" might explore together.

So political leaders, we shall see, can exhibit and model pathological behaviors as well as healthy ones. If they model blame games, they encourage and teach us to blame others. If they play fast and loose with the facts, exaggerating here and speculating wildly there, they encourage us to do the same, to treat science as mere opinion, to treat self-serving rationalization not as selfishness but as innocuous behavior.

Perhaps this is not too strong: blame undermines compassion. Blame substitutes finger-pointing for the outstretched hand. Blame speaks more to "what is wrong with you (or them)" than to "what we can do together now." Blame substitutes (1) the allocation of responsibility for (2) the practical kindness, the actual collaboration, of compassion.

But notice also that when we blame another person, we don't just label them - "guilty" or "responsible" or "at fault" for example—but we are drawn to supply a relevant history. We are pulled not only to say, essentially, "You (or they) are responsible for this trouble," but to do more; we feel the need to explain, to justify, to rationalize, to come up with a compelling story, a reading of history that supports us. This helps us to understand, as a result, that just as blaming shifts attention away from the practical issue of what needs to be done-from evidence-based analysis and argument to a question of another's past action-blame's first cousin is rationalization and potential mis-information.

In the time of COVID-19, for example, responding to the vulnerabilities of those in schools or nursing homes, those at work or now unemployed, requires inquiry and learning, both listening to the infected to learn about their asymptomatic and symptomatic experience and widespread, careful testing to learn about who's actually and potentially affected. In the face of pandemic uncertainty and complexity, compassion depends as much upon knowledge as upon empathy, as much upon trustworthy epidemiological information as upon the stories of the economically and spatially displaced. ${ }^{12}$ So what can undermine compassion, then, along

\footnotetext{
12 What damage, for example, does the COVID-19 virus do to the body beyond the lungs? Does the virus change or mutate over time? Then, too, complementing these "known unknowns," the questions that we can frame but not yet answer, we can also expect to need to learn about "unknown unknowns": new questions that will be important to study, even if we cannot specify them now. All this requires a humility and openness to scientific inquiry, a disposition to learn, not simply to assert that we are now in control.
} 
with attention-distracting strategies of blame, is the willful disregard of evidence and scientific findings, along with the failure to ensure necessary testing in the first place. Just as pernicious is the casual dismissal of the institutions of science-the norms of testing, the wariness of bias, the commitment to a practical objectivity (the freedom from "it's true because I say so"). ${ }^{13}$

\subsection{Mis-information as an obstacle to compassion}

In the time of COVID-19, the public conversations about "reopening" states—or compelling workers at meat-packing plants to remain at work-provide stark examples of the dangers posed by willful mis-information. Even as public health experts warn of resurgent contagion, of second waves, of substantial health risk, we see political leadership ignoring warnings, not sharing information, and arguablygiven expert commentaries-encouraging false hopes that reopened economies might revert to "normal" quickly and effortlessly.

But mis-information can take subtly diverse forms. ${ }^{14} \mathrm{~A}$ television personality might be mis-informed, and so they might lead us to believe something that's just nonsense (e.g., miracle-drugs). A "company doctor" might lead us to consent to, or accept, a procedure or behavior we think to be legitimate when it's actually harmful (e.g., biased advice). Or apparently sincere promises can lead us to trust someone when they're deceiving us. But the most dangerous obstacles to compassionate actions might combine all three of these elements-as, for example, when President Trump reassured his audiences by promoting hydroxycloroquine as a remedy for the COVID-19 virus, a suggestion that no rigorous medical testing supported.

Still other misinformation can hide malfeasance or provide a fig-leaf for a poor excuse for inaction: "Someone

\footnotetext{
13 Think about using a map to find a friend's recommended restaurant. If you have no assurance that the map bears a vetted relationship to the location you're in, if you think the map-maker's been more concerned with their own business connections than with any accuracy of street names or consistencies of scale, you'd be a fool to "use the map." Similarly, we might hesitate to trust the judgments of someone when we know they have had several too many drinks; we may wait till morning, or a few mornings, to have a conversation that we might still need to have. If a speaker's words tells us more about their own biases than it tells us about the world, we had better take care-their information is unlikely to help us act very well on matters we care about.

14 In urban planning, "mis-information" has revealed issues of power relationships, agenda-setting, and selective attention (Forester 1989, chapter 2).
}

should have told us about this danger... we didn't know about it earlier..." even as national intelligence agency staff had in fact warned officials months before about the looming COVID-19 threat. In Georgia, for example, residents watched as Governor Kemp revealed his personal discovery of a day beforehand - that asymptomatic people could actually transmit the disease! — as if that had not already been publicized nationally and daily for a month.

\subsubsection{The management of belief and attention}

President Trump, for example, seems not to hesitate to spread falsehoods, but he seems to believe that as long as he has the stage, enough of his listeners will believe him, and by the time any doubts arise, other issues will be more pressing (Rich 2020). So President Trump has referred once to the looming pandemic as a non-entity, at another time as a "hoax" perpetrated by purveyors of "fake news" (he intends no irony), even as days later he predicted that the contagion would be over soon. Not long after that at the Centers for Disease Control and Prevention, he announced, again as if factually, "anybody in the country can get tested at any time." Within days, independent experts refuted all of these claims, but in the moment and on the Presidential stage of the "bully pulpit," these claims shaped public attention — but certainly not to addressing anyone's vulnerability or suffering.

\subsubsection{The management of trust}

But appeals to trust distract public attention in yet another way. When the President, for example, surrounds himself in a COVID-19 briefing with industry executives-who do not sit in the audience but stand on stage next to him, who thank him profusely for his personal leadership, and who then promise on his behalf to conduct tests and make products available, lending their brands' credibility to the President's promises - these captains of industry invoke not political authority but rather their track records of past entrepreneurial performance. They invoke no legal or ethical obligations; they pretend to carry out no mandated policy responsibilities-but they are saying, essentially, "We have built these companies, and we have been asked by the President for our cooperation, and here's what we will commit ourselves to doing..." So, without ever needing to say this explicitly, they imply, "and because we stand here at the microphone next to the President, without formal obligation, you can trust us, you can count on us, to follow through."

These presentations of corporate executives have not been accidental; presidential advisors have scripted and staged them for a particular purpose-a purpose less connected, perhaps, to the actual conduct of testing on the scale and timing that has been claimed, than to marshaling a public trust 
that we vulnerable listeners might yet be in good hands. The ship of state, we are being asked to trust- to expect because of these promises-is acting to meet our needs, not actually floundering on the rocks of the pandemic. But "trust me," of course, asks for deference, not for independent thought and action, not for community mutual aid or collaboration. ${ }^{15}$

\subsubsection{The management of consent and authority}

But notice that the White House's orchestrated displays of mis-information take still other creative, if suspect, forms. Appealing to trust alone might not win over enough of a fearful, vulnerable, and wary audience. So the daily briefings have carefully staged, presented, and invoked the recognized authority of well-established expertise, that most notably of Drs. Anthony Fauci and Deborah Birx. ${ }^{16}$

The commentaries, advice, and warnings of Drs. Fauci and Birx did not depend on claims of trust or their personal agreements with the President. Their words invoked not simply the record of their personal accomplishments, but the critical institutions of medical research, the authority of critically vetted, scientifically tested analyses. Their claims included, acknowledged and recognized competing, critically developed, predictive epidemiological models. Here, they argued, we can estimate the behavior of the contagious virus, depending on a set of transparently debatable assumptions that vary, for example, social distancing behaviors and policy responses.

What Drs. Fauci and Birx added to their medical and epidemiological predictions were, of course, their accordingly expert judgments of the possibilities and contingencies of

\footnotetext{
15 Could there be a more stark contrast to President Kennedy's famously inspiring "Ask not what your country can do for you; ask what you can do for your country"? But the management of trust has a dark side that we see far too perniciously in what Neema Kudva (in correspondence) has called the "demonization of the other," fueling the polarization and character assassination (of "liberals" or "fake news reporters", for example) that has threatened to make practical political conversations-that are more necessary than ever-actually more toxic than ever. Cf. Bhatia (2020).

16 Dr. Anthony Fauci is Director of the National Institute of Allergy and Infectious Disease, one of 27 Institutes in the National Institute of Health, an Agency of the US Department of Health and Human Services. In that capacity he is the "go to" scientist where COVID-19 is concerned for the federal (national) government. Dr. Fauci is one of the world's leading experts on infectious diseases: if one ignores him, one is ignoring science. He has served every President since Ronald Reagan. Similarly, Dr. Deborah Birx is a physician and diplomat who served with the US Global World Aids Coordinator under President Obama. President Trump and Vice President Pence chose her to be the Coronavirus Response Coordinator, working with Dr. Fauci on the President's "White House Coronavirus Task Force" which held daily public briefings from March 16 through April 25, 2020. Dr. Fauci and Dr. Birx represented the voice and authority of the U.S. scientific community on that Presidential Task Force.
}

"flattening the curve" of contagion and deaths. They asked not for trust of persons but for consent to authority; they appealed not to promises but to the merits. Their practical professional judgments, they claimed, depended on the predictions and explanations that other critically informed analysts corroborated (Sharpe 2020).

But consider, for example, the White House's recent $(5 / 5 / 20)$ announcement that they intended to prevent Dr. Fauci from testifying to Congress. At stake here was not simply medical knowledge, but the influence of scientific legitimacy. Here the power of the bully pulpit, the power of the President to shape public attention, threatened to muzzle an expert who might share his professional judgments about the human costs of this administration's needless delay, their disregard of intelligence reports, and their inabilities to mandate the immediate production of medical and personal protective equipment for hospitals.

At stake here, then, is neither simple belief and factual information nor interpersonal trust, but the public's capacity for understanding, their intelligence: The public's critical consideration of a professional judgment not just about what could have been done earlier by authorities, but about what should have been done, given the information available at the time. Here we see that the prize to be won or lost involves not just trust but legitimacy, not just deference but consent, not just good intentions but competence, not just lacking leadership but the recognition of irresponsibly handled authority.

\section{Rescuing compassion from its foes; from blame and misinformation to possibilities of confidence, hope and action}

But as blame games or misinformation went on, so did the contagion of the COVID-19 virus. New Yorkers "flattened the curve," but Floridians went back to the beaches. Meatpacking plants have hundreds of positive cases; nursing home deaths number in the tens of thousands. Forty million workers in the USA are unemployed. So what are the prospects of compassionate response?

We have seen that fear and anger, blame and misinformation can undermine compassion and the collaboration that it requires. We turn to examine more closely, now, how in the time of COVID-19 public leadership can undermine or encourage practices of compassion.

As we will see in more detail below, the daily briefings of President Trump's COVID-19 Task Force and New York State Governor Andrew Cuomo have been instructive. At times their use of expertise has been sobering and humbling; they have warned, for example, against over-confidence-not to discourage compassion but indeed to urge its 
continuance. This is no time to let up, no time to back off of social distancing. Both briefings have shown models; both have made efforts toward transparency, and with guidelines for the public they have encouraged step-wise compassionate actions of maintaining caution, maintaining distance, wearing masks to protect others, and more.

Although the White House briefings have hardly had the consistency of message, prediction, and advice that the Governor's have had, both make gestures toward a transparency by taking questions from the press. Although the President's attacking reporters who ask critical questions belies his transparency and accountability, Governor Cuomo typically refers these questions to experts or Department heads, offers an explanation, or says quite directly, "I don't know."

Both the President and Governor express appreciation of first responders and their own staff and Task Force members. The President famously stands behind his "I take no responsibility" (apparently for having made any mistakes); he asks instead for appreciation because he and his Task Force have things well in hand (even as they redefine central problems differently each few weeks). Governor Cuomo in contrast seems not to need to be omniscient or fully in control, and his frequent appeal, "We need to learn from all this," encourages compassion as much for its implication that we need to learn about our common threats and remedies (so we can act better) as for its inclusive use of "we," a gesture to what we can do together.

President Trump conveys that "this will be over some day." Governor Cuomo, in contrast, conveys, "We can meet these challenges together." Trump celebrates what he has done and castigates others for not doing more. Cuomo appeals consistently to the facts, the experts, to science, to the step-wise moves that might allow both safety and economic renewal.

Trump appeals to market forces without apparent worry about market failures. Cuomo, stuck in the market failures of states' bidding against each other, suggests strategies of governance (via the Defense Production Act, for example) that might overcome market failures and enable effective and compassionate care in our hospitals, public or private.

Trump appears to convey, "Trust us; my team has this in hand." Cuomo conveys, "We have to listen to the experts and respond; we have to learn as we go; we can do this if we do this together."

What can we learn then, not about informing "hope" in the abstract, but about promoting realistic and actual confidence in what we can do together in response to the threats of pandemic? The effective action that has been most available to ordinary citizens has been clear: keeping one's social distance. And the efficacy of that widespread compassion, those steps taken so that asymptomatic carriers of the virus do not spread the virus to others, has been striking — where it has been carefully and widely practiced, as in, most notably, New York and California. But even as schools and businesses in many places closed down-at Governors' requests and in response to experts' testimonies-and are struggling now with how to "reopen," many difficulties persist.

Leadership matters here, not so much formally but interactively, shaping our relationships with one another. Even socially, we show one another how to go on all the time. Whether as friends or acquaintances we show each other how to treat each other, how we might treat members of our families, how we might treat others, what we might wear, what we might cook, how we might think of both future and past. And so all the more, facing the striking issues of the day, whether they involve race or immigration or public safety or taxation and public spending, our political leaders who hope to maintain our votes and confidence take public stances that they hope will not just gain favor but show us a way forward together.

So leadership in many forms-from our elders or young innovators, from local, state, or federal politicians tooeffectively exhibits and models not just instances of behavior for us, but our possible ways of addressing one another and our futures. Those elders, innovators and leaders do not so much lecture us about this or that but they show us how we might act; they exhibit and model more or less compassion, more or less empathy, more or less blaming and fearing the Other, more or less competent strategies of action, and not least, more or less dignity and moral integrity (Forester 1999).

In blaming others, such "leadership" takes not encouraging, large steps forward to solve problems but instead distracting, great leaps backwards-backwards because in ignoring intelligence and careful analysis, in putting aside the standards of vetting and science, such leadership makes us not more informed but more stupid. It makes us not a more critical public but a less thoughtful, if more a reactive and willful one.

When public leadership indulges in blame games, it encourages us, too, to become more strident, more divided, more suspicious of others' competence and motives, and we become all the less likely to act together in concerted ways to cooperate to solve problems. We are asked to be spectators pointing fingers; we are not asked what we can do to contribute to the public welfare. For example, President Trump has blamed Governors and states for not knowing where crucial medical supplies were, for not properly organizing COVID19 testing. Governor Cuomo, in contrast, routinely has asked not just for his listeners' attention but for their help: not just for social distancing but for medical volunteers, for the respect, and appreciation for first responders, for PPE (personal protective equipment), and more. The daily "Coronavirus briefings" of President Trump and Governor Cuomo 
have illustrated these contrasting strategies of responding to pandemic fears in poignant, stark, and instructive detail.

\section{A natural experiment as fear and confidence both influence compassion}

We have argued, so far, that both (1) the public fear of contagion, sickness, and possible death-this widespread sense of vulnerability-as well as (2) the public confidence in modes of response are themselves products of social interaction, public leadership, and public policy. The fears of contagion led to widespread attention to epidemiological commentary with clear and immediate professional recommendations: rigorous hand-washing, avoidance of touching one's mouth, nose or eyes, and social distancing, including the wearing of masks. At the same time, we have seen that these fears have led to anger: "Why weren't we told about this? Why weren't we prepared? Why are we running out of surgical masks in the most advanced technological economy in the world? Why does the federal (national) government's response seem so inept, so slow, so contradictory, so weak? Why does the federal government tell us that widespread national testing is the states' responsibility - as if in a time of war each state government would bear the responsibility of producing its own airplanes, ships, and armaments?"

Such doubt, uncertainty, anxiety, and anger resulting from COVID-19 fears drove a diverse array of reactions, from those capitalizing upon these fears (e.g., by marketing ineffective diagnostic tests) to those channeling them to address the pandemic's threats for the broader public interest. At several of his daily press briefings, for example, President Trump notoriously and controversially encouraged listeners to try administering untested drugs and even household disinfectants as powerful as bleach. At the same time, New York Governor Andrew Cuomo held daily public health briefings as well, as he updated New Yorkers about the crisis of hospitalizations in New York City. Those parallel, daily press conferences allowed a bit of a natural experiment. Viewers were able to compare, roughly_-given the same looming threat of the pandemic, with New York City as its epicenter in the USA-how these differing federal (national) and state responses worked to shape public understanding, public fear and confidence, the public's sense of vulnerability and safety.

Beginning from a condition of widespread fear and uncertainty, these parallel briefings showed two quite different directions of developing public sentiment and response: (1) one that tried to dismiss fear and emphasize an imminent return to normality, by maintaining the semblance of control in part by holding expertise at a distance, and (2) a second that tried less to control a message than to educate the public about the pandemic, possible strategies of response, details about current hospitalizations, hospitals' capacities, and rates of new cases, intubations and deaths-all in hopes of motivating social distancing and soliciting volunteer assistance, all to organize concerted public action and confidence in response.

These two daily briefings provided a public education in the ways that leadership might enable quite different modes of compassion and collaboration. The White House briefings at first discounted the pandemic's threat as a hoax, then as time limited and passing soon, then as requiring the expert reassurance of Drs. Fauci and Birx that someone was after all minding the store and watching the spread of the disease. The White House then just as explicitly denied responsibility for a slow federal response, but marshaled the presence and reputations of private business leaders in tandem with targeting blame upon others. In these briefings, the President blamed the states for not knowing where needed equipment was; he blamed the World Health Organization for being slow to warn the West; he blamed the intelligence services for being asleep at the wheel—even as subsequent news reports claimed that the President's daily intelligence briefings had in fact warned him of the looming pandemic months before he addressed it. Nobody knows whether the President had actually read those reports.

Viewers witnessed, too, as we have detailed, the White House's care-it is an election year, after all-to shape trust in its good intentions and to shape consent and deference to its use of expertise and governmental regulations, even to the point of arguing that the responsibility for nationwide testing fell not to the federal (national) government but to the individual states.

The parallel briefings of New York Governor Cuomo were no less complex, but they were edifyingly and practically different. The Governor stressed the daily updating of facts, the anticipated needs, the state's need for coordination with the federal government, the experts' modeling of threatened spread and the social distancing that might "flatten the curve." The Governor was quite explicit about blame as a luxury that he-though he said "we"-could ill afford; the problem now was not to debate who was and was not really to blame; the problem now was what to do, how to obtain PPE, how to obtain and perhaps share ventilators, how to provide the needed intensive care beds, and so on. The "no time for blame" claim - even if that time will surely come later-teaches us a lesson in the moral economy of attention: if we invest resources now in assigning blame, we will be diverting resources of brains, time, imagination, problemsolving capacity from saving lives_-and people will die.

This lesson, we should note, also concerned hope and confidence, next steps to be figured out and needs that a "we" can address collaboratively_instead of falling into the 
strategy that the White House briefings seemed to adopt. The White House seemed to suggest: "There is the problem, there are the agents responsible, we here are not responsible, but are in charge. We are doing great work on our Coronavirus task force, and we should be appreciated and celebrated!-instead of being asked such difficult questions by the press (Bump, 2020). As we have argued, blame can easily, and very practically, distract attention from the pressing needs for locally responsive problem-solving. So the Minnesota COVIDSitters's volunteers organized support for the families of hospital workers putting in 15 hour shifts, "including custodians, cooks and other essential employees." In New York neighbors in Bed-Stuy Strong brought food and supplies to sick and locked down residents-and examples of such collaborative, compassionate mutual aid abound (Tolentino 2020).

Conversely, attention to problem-solving can not only put blame aside for the moment, but it can coordinate efforts to respond to human need. We can learn here, too, from Cathleen Kaveny's striking analysis of prophecy and climate change (Kaveny 2016). Kaveny argues that shared understanding and agreement are necessary if any successful prophetic indictment of wrong doing is ever to be persuasive. Although nobody disputes the moral imperative to avoid damaging the environment, Kaveny observes that underlying facts remain in dispute. In subsequent discussion with McKibbon, she clarified that even as the climate science is undeniable, many "deniers" remain skeptical of the facts as well as of the science. We must, apparently, explain both the sciences and the facts-as Drs. Fauci and Birx continue to do-as often and as many times as possible. Emphatic denunciation of the deniers will hardly persuade them to think otherwise.

In the pandemic's case, all the more because there is no current vaccine or technical fix, the strategies of response required and addressed in the Governor's briefings were not simple but complex, were not easily controlled from the top down but required widespread public cooperation. These responses were not simplistic and unambiguous but instead were data-dependent, data-driven, not in any government's control, neither the state's nor the national government's.

The Governor's briefings stressed not political power and any leader's control but instead the collective vulnerability of every person in New York State, and the collective significance of every person's responsibility in New York State to collaborate effectively by social distancing - because, of course, asymptomatic people of any age or color or class or income or religion could carry the virus and could infect others.

These briefings by Governor Cuomo, then, cautioned listeners about over-confidence as the curve flattened; they stressed not individual but community members' responsibilities to one another, responsibilities to keep each other safe, responsibilities of respect and care. Rather than working from fear to anger to blame, these New York State briefings worked from fear to learning to actions to care for one another, a progression from fear to hope, not from fear to wishful thinking or fantasy or dreams, but from fear to well-informed confidence about what "we can do," how we can effectively collaborate, to a confidence not just about action but also about who we can be, in doing what we need to and ought to do. And New Yorkers responded and flattened the curve, with the help of 90,000 heath care and associated volunteers who answered that call for help, with community based mutual aid (Tolentino 2020), and of course, with widespread, collaborative and disciplined social distancing.

Yet for all of Governor Cuomo's call for the facts, for testing, for science, and for all of his hope to put aside emotions so that we can follow the best advice of the scientists and the epidemiologists, the Governor worked to reshape his audience even as he informed it. Governor Cuomo asked his listeners to imagine themselves as a community who have respect not only for one another's vulnerabilities and potential suffering but for the integral role of scientific inquiry and professional judgment too. Where the White House appeared, repeatedly, to distrust intelligence services, to distrust expertise, to devalue science, the Governor did not treat science as infallible but rather as an institution of fallible but pragmatically refined, emergent collective intelligence that his listeners could hardly afford to ignore or dismiss, if they wished to live together, and in the case of the pandemic, if they wished to live at all.

So, we see how Trump and Cuomo invoked and sought to enact different conceptions of citizenship (Lebano 2020). The White House seemed to evoke not so much the sentiments and responsibilities of political citizenship, in fact, but those of independent consumers - and if these consumers wanted to try to inject disinfectants, that's their business. The motto of the White House briefings might have been, "Buyer Beware!"

Governor Cuomo had a less sanguine view of a technologically and biologically complex marketplace: In a world of bewildering interdependence and spill-over effects, costs, and vulnerabilities, the buyer who wishes to "beware" needs not just information but measures of protection. These buyers need not only a market so they might be consumers; they also need a sense of community in which we will wear masks to prevent sickening one another, to take concrete steps to care for one another. These buyers will also need a government informed by intelligence, disciplined by science, to staff fire departments to respond to flames next door, to catch pandemic threats early, not months too late; to combat sea-level rise decades before unnecessary flooding.

\section{Conclusions}

What we see, then, is that the COVID-19 pandemic teaches us not just about sickness and medical pathologies, but about pathologies of response to fear and vulnerability as 
well and the potential creativity of a critically designed compassionate approach. We see that responses to fear and vulnerability can take more or less compassionate paths. The least compassionate response involves focusing on blaming others and avoiding responsibilities of our own, bolstered by strategies of misinformation, keeping others more ignorant and ill-informed than they might be, more blindly consenting than critically collaborating, more gullibly trusting than acting together mutually, in concert, to care for one another. ${ }^{17}$

The more compassionate path in response to fear and vulnerability does not dismiss either empathy or science; it recognizes interdependence and uncertainty, the need for inquiry and testing and pragmatic steps forward with revision and accountability made possible by transparency, by fostering a community of mutuality and critical intelligence, a community of members who will keep each other honest, who will beware cooking the data, who will collaborate to protect each other and our common welfare.

But compassion and the collaboration it depends upon do not come easy, and both are vulnerable to the fearful responses of blame games and the willful dis-organizing of hope and confidence, the dis-organizing of scientific inquiries, of conditions enabling well-informed political consent, and not least of all, the dis-organizing of means of transparency that safeguard social trust. Yet in embracing inquiry and analysis, critical discourse and transparency, and not least of all, mutual aid, we can develop confidence and organize hope, integrating compassion, collaboration and planning to move toward shared visions of post-pandemic health.

Acknowledgements We are grateful for critical readings and detailed comments to: Howell Baum, Wayne Caldwell, Ben Davy, Neema Kudva, David Laws, Adele Lebano, Ann McKibbon, Emily McKibbon, and Leonie Sandercock.

\section{References}

Bhatia R (2020) My health today, or your health tomorrow. Medium (on line), May 15
Bump P (2020) Without Trump at the coronavirus briefings, America would get more information from the experts. The Washington Post, April 26

Forester J (1989) Planning in the face of power. University of California Press, Berkeley

Forester J (1999) Deliberative practitioner. MIT Press, Cambridge

Forester J (2009) Dealing with differences: dramas of mediating public disputes. Oxford University Press, Oxford

Forester J (2020) Our curious silence about kindness in planning: challenges of responding to vulnerability. Plan Theory. https://doi. org/10.1177/1473095220930766

Innes J, Booher D (2010) Planning with complexity: an introduction to collaborative rationality for public policy. Routledge, New York

Institute on Trauma and Trauma-Informed Care. What is traumainformed care? http://socialwork.buffalo.edu/social-research/insti tutes-centers/institute-on-trauma-and-trauma-informed-care/whatis-trauma-informed-care.html. Accessed 14 May 2020

Kaveny C (2016) Prophecy without contempt: religious discourse in the public square. Harvard University Press, Cambridge

Lebano A (2020) Sweden's relaxed approach to COVID-19 isn't working. Boston Review, May 8

Lorde A (2017) A burst of light: and other essays. Ixia Press, Mineola

Lyles W, White SS, Lavelle BD (2017) The prospect of compassionate planning. J Plan Lit 33:1-20

McKibbon E (2020a) Personal correspondence with the authors of this article. May 13, 2020

McKibbon G (2020b) Planning during and after the age of COVID-19. Newsletter of the Western New York Section of the American Planning Association, April

Nussbaum M (2014) Compassion and terror. In: Ure M, Frost M (eds) The politics of compassion. Routledge, London, pp 189-207

Nussbaum M (2016) Anger and forgiveness. Oxford University Press, Oxford

Nussbaum M (2018) The monarchy of fear. Simon and Schuster, New York

Pamuk O (2020) What the great pandemic novels teach us. New York Times, April 23

Polland B, Parkes MW, Hancock T, McKibbon G, Chircopp A (2020) A changing role for public health in the anthropocene: the contribution of scenario thinking in re-imaging the future. In: Zywert $\mathrm{K}$, Quilley S (eds) Health in the anthropocene: living well on a finite planet. University of Toronto Press, Toronto

Rich F (2020) Trump lies his way through a pandemic. New York Magazine, March 20

Sharpe K (2020) Learning the wisdom to seize the moment. Negot J 36(2):169-188

Shklar J (1990) The faces of injustice. Yale University Press, New Haven

Tolentino J (2020) What mutual aid can do during a pandemic. The New Yorker, May 18 issue

\footnotetext{
17 Emily McKibbon, Associate Director/Senior Curator at the McLaren Art Centre, Barrie, Ontario, notes here, "It's also, arguably, one of the only times we're offered empirical evidence of the need for collective action: the models, showing what happens with physical and social distancing vs without (the most compassionate vs the least compassionate or the community who thinks of others vs. the individual consumer)." (McKibbon 2020a).
} 


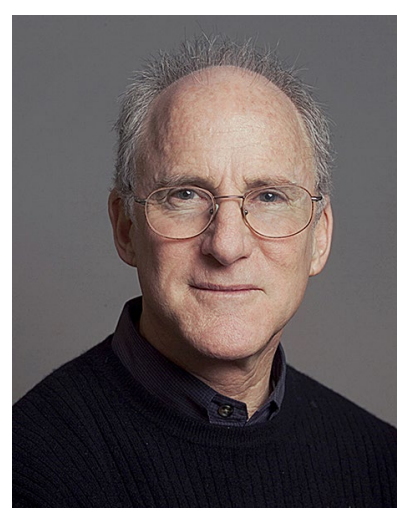

John Forester is a professor of City and Regional Planning at Cornell University, USA. He has explored practices of power, deliberation, and dispute resolution in, respectively, Planning in the face of power (1989), Deliberative practitioner (1999), and Dealing with differences (2009). His current research involves practical judgment and improvization in complex cases.

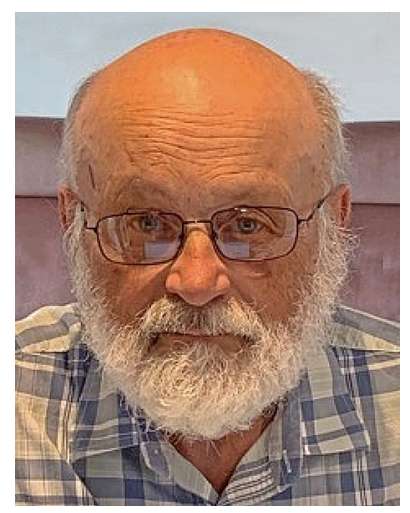

George McKibbon is a land use planner with 46 years of experience. He is an Adjunct Professor in the School of Environmental Design and Rural Development, University of Guelph, and a sessional lecturer in the W Booth School of Engineering Practice and Technology, McMaster University. 